\title{
ANALISIS JUMP SHIP CREW ON BOARD PADA PT KARYA SUMBER ENERGY
}

\author{
Kurnia Faiztri Susanto ${ }^{1}$, Andy Wahyu Hermanto ${ }^{2}$ \\ ${ }^{1 \& 2}$ Program Diploma IV Ketatalaksanaan Angkutan Laut dan Kepelabuhanan \\ Politeknik Ilmu Pelayaran Semarang \\ Jln. Singosari 2A Semarang \\ Kurniafaiz53@gmail.com
}

\begin{abstract}
Abstrak
Jump Ship Crew On Board merupakan permasalahan yang sering terjadi di perusahaan pelayaran khususnya perusahaan yang menangani rekrutmen crew kapal dimana crew kapal tersebut meninggalkan kapal dan tanggungjawabnya sebagai awak kapal, dan hal ini dapat menimbulkan kerugian bagi perusahaan. Tujuan dari penelitian ini yaitu untuk mengetahui dan menganalisa penyebab dan dampak yang timbul dari jump ship crew on board serta upaya yang dilakukan untuk mencegahnya. Penelitian ini menggunakan metode deskriptif kualitatif dengan mendeskripsikan secara terperinci permasalahan jump ship crew on board pada PT Karya Sumber Energy. Pengumpulan data dilakukan dengan wawancara, observasi, literatur dan dokumentasi. Hasil penelitian menunjukkan bawa, penyebab terjadinya jump ship crew on board ada 2 (dua) faktor yaitu faktor internal yang berasal dari crew kapal itu sendiri dan faktor eksternal yang berasal dari kesalahan pihak PT Karya Sumber Energy. Dampak yang timbul dari jump ship crew on board pada PT Karya Sumber Energy dapat dilihat dalam bidang operasional, personalia dan financial. Selanjutnya, upaya yang dilakukan oleh PT Karya Sumber Energy untuk mencegah jump ship crew on board adalah dengan melakukan pembagian kerja, memperketat proses rekrutmen crew kapal, serta membangun komunikasi yang baik.
\end{abstract}

Kata Kunci : Analisis, Jump Ship Crew, dan On Board

\section{PENDAHULUAN}

Crew kapal merupakan orang yang bekerja diatas kapal sebagai bagian dari awaknya, dan dapat bekerja dalam salah satu dari sejumlah bidang yang terkait dengan operasi dan pemeliharaan kapal. Hal ini mencakup seluruh orang yang bekerja diatas kapal. Untuk menjamin keselamatan pelayaran sebagai penunjang kelancaran lalulintas kapal diperlukan oleh awak kapal yang memiliki keahlian, kemampuan dan terampil. Dengan demikian setiap kapal harus diawaki dengan awak kapal yang terampil untuk melaksanakan tugasnya sesuai dengan jabatan dengan mempertimbangkan tonase kapal dan permesinan kapal.

Dewasa ini sekolah-sekolah pelayaran baik negeri maupun swasta telah banyak meluluskan ribuan pelaut muda yang siap bekerja, namun dihadapkan dengan armada kapal perusahaan pelayaran yang terbatas. Oleh sebab itu, hal ini menimbulkan persaingan yang semakin sulit untuk mendapatkan pekerjaan.

Disaat peneliti melaksanakan observasi di PT Karya Sumber Energy, setiap hari CV (Curriculum Vitae) atau surat lamaran pekerjaan yang masuk ke PT Karya Sumber Energy sebagai crew kapal untuk seluruh jabatan yang ada di kapal sangat banyak. Tetapi dalam pelaksanaan operasional armada kapal PT Karya Sumber Energy penulis mendapati 7 (tujuh) crew kapal melakukan jump ship atau kabur meninggalkan kapal dan melepas tanggung jawabnya sebagai awak kapal atau crew kapal tanpa perintah dari perusahaan.

Hal tersebut membuat peneliti tertarik untuk mengadakan penelitian mengenai jump ship crew kapal dengan judul Jump Ship Crew On Board Pada PT. Karya Sumber Energy.

Tujuan dari penelitian ini ialah untuk mengetahui dan menganalisa penyebab jump 
ship crew on board pada PT Karya Sumber Energy, mengetahui dampak jump ship crew on board pada PT Karya Sumber Energy. Sedangkan manfaat penelitian ini secara teoritis adalah sebagai tambahan ilmu dan pengetahuan umum bagi pembaca, termasuk pihak-pihak yang terkait dan diharapkan penelitian ini dapat memberikan masukan dalam pengembangan sumber daya manusia dan dalam menjalankan manajemen operasional kapal. Sedangkan manfaat secara praktis sebagai referensi untuk melakukan perbaikan dan koreksi bagi PT Karya Sumber Energy dalam menjalankan bisnis operasional dan manajemen kapal.

\section{LANDASAN TEORI}

Analisis

Menurut (Prastowo \& Juliaty, 2002), kata analisis adalah Penguraian suatu produk atas berbagai bagiannya dan penelaahan bagian itu sendiri, serta hubungan antar bagian untuk memperoleh pengertian yang tepat dan pemahaman arti keseluruhan.

Menurut Peter \& Salim (2002), analisis adalah penyelidikan terhadap suatu peristiwa (perbuatan, karangan, dan sebagainya) untuk mendapatkan fakta yang tepat (asal usul, sebab, penyebab sebenarnya, dan sebagainya).

Sedangkan menurut Kamus Besar Bahasa Indonesia (2001), Analisis adalah penyelidikan suatu peristiwa (karangan, pembuatan, dan lainnya) untuk mengetahui keadaan yang sebenarnya (sebab, musabah, duduk perkaranya, dan sebagainya) penguraian suatu pokok atau berbagai bagiannya dan penelaahan bagian itu sendiri serta hubungan antar bagian untuk memperoleh pengertian yang tepat dan pemahaman arti keseluruhan, dikaji sebaikbaiknya, proses pemecahan persoalan yang dimulai dengan dugaan akan kebenarannya.

Berdasarkan definisi diatas dapat disimpulkan bahwa analisis adalah kegiatan untuk memecahkan masalah dan melakukan suatu penyelidikan untuk menemukan suatu sumber suatu masalah sehingga dapat memecahkan masalah. Dalam hal ini adalah analisis jump ship crew on board pada PT Karya Sumber Energy.

\section{Jump Ship}

Jump ship jika diartikan kedalam Bahasa Indonesia adalah lompat kapal. Jump ship merupakan istilah yang sering digunakan dalam dunia pelayaran untuk mendiskripsikan suatu kejadian awak kapal atau crew kapal yang kabur meninggalkan kapal dan melepas tanggungjawabnya sebagai awak kapal. Kata kabur dalam Kamus Besar Bahasa Indonesia (2001), memiliki arti meninggalkan tugas (pekerjaan, keluarga, dan sebagainya) tanpa pamit: menghilang.

Menurut Burhanudin (2000), menjelaskan bahwa tanggungjawab adalah kesanggupan untuk menetapkan sikap terhadap suatu perbuatan yang diemban dan kesanggupan untuk memikul resiko dari suatu perbuatan yang dilakukan.

Aspek kepuasan kerja merupakan hal yang penting agar jump ship tidak terjadi. Levi (2002), ada beberapa aspek yang ada dalam kepuasan kerja, yaitu:

\section{Crew on board}

Dalam Bahasa Indonesia arti kata crew adalah awak kapal Menurut Undang Undang Republik Indonesia No. 17 Tahun 2008 tentang Pelayaran Bab 1 Ketentuan Umum Pasal 1 Ayat 40, “Awak kapal adalah orang yang bekerja atau dipekerjakan di atas kapal oleh pemilik atau operator kapal untuk melakukan tugas diatas kapal sesuai dengan jabatannya yang tercantum dalam buku sijil". Dalam ayat 41 juga di sebutkan "Nakhoda adalah salah seorang dari awak kapal yang menjadi pemimpin tertinggi di atas kapal dan mempunyai wewenang serta tanggung jawab tertentu sesuai dengan perundang undangan." Menurut PP RI No.51 Tahun 2002 tentang Perkapalan "Anak buah kapal adalah awak kapal selain nakhoda ataupun pemimpin kapal "Semua posisi yang di kapal baik perwira maupun rating merupakan awak kapal. 
Sedangkan on board dalam bahasa Indonesia memiliki arti di atas kapal atau orang yang sedang berada di atas kapal, dengan demikian dapat disimpulkan bahwa crew on board adalah orang yang bekerja dan diperkerjakan di atas kapal sesuai dengan tugas dan tanggung jawabnya sebagai crew kapal yang telah di tunjuk olah pemilik kapal atau operator kapal dengan yang tercantum dalam sijil buku pelaut.

\section{Kerangka Pikir}

\begin{tabular}{|c|}
\hline JUMP SHIP CREW ON BOARD \\
PADA PT KARYA SUMBER \\
ENERGY \\
$\downarrow$
\end{tabular}

\begin{tabular}{c}
\hline $\begin{array}{c}\text { Faktor Penyebab Jump Ship } \\
\text { Crew Pada PT Karya Sumber } \\
\text { Energy }\end{array}$ \\
$\downarrow$
\end{tabular}

\begin{tabular}{|c|}
\hline $\begin{array}{c}\text { Dampak Jump Ship Crew Pada } \\
\text { PT karya Sumber Energy }\end{array}$ \\
$\downarrow$
\end{tabular}

\begin{tabular}{|c|}
\hline Pengumpulan Data: \\
Studi Pustaka \\
Observasi \\
Wawancara \\
Dokumentasi \\
$\downarrow$
\end{tabular}

\begin{tabular}{c}
\hline $\begin{array}{c}\text { Metode penelitian } \\
\text { Deskriptif Kualitatif }\end{array}$ \\
$\downarrow$
\end{tabular}

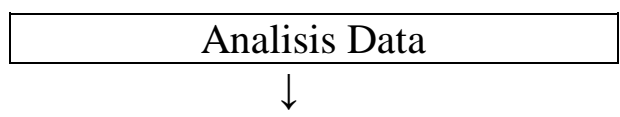

\section{Jump Ship Crew On Board pada PT Karya Sumber Energy dapat di minimalisir}

Gambar 1 Kerangka Pikir

Menurut Uma Sekaran dalam Sugiyono (2011 : 60) mengemukakan bahwa Kerangka berpikir merupakan model konseptual tentang bagaimana teori berhubungan dengan berbagai faktor yang telah diidentifikasi sebagai hal yang penting.

Untuk memudahkan pemahaman terhadap pemaparan ini, maka peneliti membuat kerangka pikir dalam bentuk bagan sederhana yang dilengkapi dengan penjelasan singkat mengenai faktor penyebab, dan dampak, yang terjadi dalam pembahasan permasalahan jump ship crew on board pada PT Karya Sumber Energy.

\section{METODE PELELITIAN}

\section{Objek Penelitian}

Menurut Sukardi (2013) dalam bukunya Metodologi Penelitian Pendidika dan Praktiknya, tempat penelitian yaitu tempat dimana proses studi yang digunakan untuk memperoleh pemecahan masalah penelitian berlangsung. Adapun lokasi penelitian dilaksanakan di PT. Karya Sumber Energy yang beralamatkan di Jl. Kopi No 2F Tambora Jakarta Barat pada tanggal 1 Agustus 2018 sampai 24 Agustus 2019 yang dilaksanakan peneliti saat melaksanakan Observasi di PT Karya Sumber Energy.

\section{Metode Pengumpulan Data}

Metode pengumpulan data merupakan cara yang digunakan untuk mendapatkan data dalam penelitian. Penelitian ini menggunakan jenis penelitian kualitatif sehingga data yang diperoleh harus jelas dan spesifik. Pengumpulan data penelitian kualitatif diperoleh dari hasil observasi, wawancara, diskusi, studi dokumen (Sujarweni, 2015). Menurut Jonathan (2006) dalam bukunya Metodologi Penelitian Kuantitatif dan Kualitatif, metode pengumpulan data adalah metode yang dilakukan melalui keterlibatan secara langsung dengan objek yang diteliti. Penulis menggunakan metode dibawah ini untuk mendapatkan informasi yang diperlukan, yaitu sebagai berikut: 


\section{Studi Kepustakaan}

Menurut Sukardi (2013) dalam bukunya Metodologi Penelitian Pendidikan dan Praktiknya, studi kepustakaan adalah mencari dasar-dasar acuan yang erat kaitannya dengan masalah penelitian yang dilakukan, dasar-dasar acuan tersebut terdiri dari berbagai sumber yang kemudian disusun dalam bab tersendiri. Dalam hal ini peneliti mendapatkan referensi dari pustakaan Politeknik Ilmu Pelayaran (PIP) Semarang, buku referensi dari internet, dan buku yang dipelajari saat melaksanakan Observasi di PT. Karya Sumber Energy.

\section{Studi Dokumenter}

Menurut Sugiyono (2006) teknik dokumentasi adalah cara pengumpulan data dengan mengumpulkan peristiwa yang sudah berlalu. Dokumen bisa berupa tulisan, arsip foto, hasil rapat, maupun karya monumental dari seseorang. Untuk memudahkan pembaca dalam memahami, dokumentasi yang digunakan harus berhubungan dengan objek yang dibahas.

\section{Studi Lapangan}

\section{Observasi}

Menurut Sujarweni (2015), observasi merupakan suatu kegiatan untuk mendapatkan informasi yang diperlukan untuk menyajikan gambaran real suatu peristiwa atau kejadian yang menjawab pertanyaan dari penelitian. Hasil observasi berupa aktivitas, kejadian, peristiwa, objek atau kondisi tertentu. Sedangkan menurut Hadi (2001) dalam bukunya Metodologi Research, observasi yaitu pengamatan dan pencatatan dengan sistemik fenomena yang diselidiki. Teknik pengumpulan data dalam penelitian ini adalah dengan mengobservasi langsung objek penelitian yaitu dengan meneliti proses yang berkaitan dengan jump ship crew on board pada saat penulis melakukan observasi PT. Karya Sumber Energy sehingga data yang dikumpulkan sesuai dengan kenyataan yang ada.

\section{Wawancara}

Menurut Hadi (2001) dalam bukunya Metode Research, wawancara atau interview adalah suatu bentuk komunikasi verbal yang bertujuan untuk mendapatkan informasi. Sedangkan menurut Sujarweni (2015), wawancara yaitu suatu proses untuk mendapatkan informasi dengan menggunakan tanya jawab dengan bertatap muka atau melalui media telekomunikasi. Dalam penelitian ini penulis melakukan wawancara guna mendapatkan informasi yang komplek. Dalam melakukan wawancara peneliti melakukan wawancara dengan karyawan dan crew kapal yang bekerja di kapal yang ditangani oleh PT. Karya Sumber Energy.

\section{Teknik Analis Data}

Analisis data kualitatif adalah kegiatan untuk mengatur, mengurutkan, mengelompokkan, dan mengkategorikan sehingga diperoleh sebuah temuan berdasarkan fokus atau masalah yang ingin dijawab (Sujarweni, 2015). Sedangkan menurut (Moleong, 2007) dalam bukunya Metodologi Penelitian Kualitatif, konsep dasar dalam analisis data akan memperoleh pengertian, waktu pelaksanan, maksud dan tujuan serta kedudukan analisis data. Dalam penelitian ini peneliti menganalisa data-data yang diperoleh dari hasil penelitian yang berupa fakta yang terjadi di lingkungan, studi pustaka serta metode dokumentasi. Kemudian peneliti membandingkan dengan teori yang ada sehingga bisa diberikan solusi untuk menjawab masalah tersebut. Penulis menggunakan model analisis mengalir (Flow Analysis Models) dimana ada tiga komponen analisis yaitu reduksi 
data, sajian data, penarikan kesimpulan/verifikasi:

1. Reduksi Data

Reduksi adalah cara merangkum, memilih hal pokok, memfokuskan pada hal-hal yang penting. Data yang ada dipelajari kemudian dilakukan pembatasan teori sehingga menjadi lebih komplek dan berisi dengan mengeluarkan data yang dianggap tidak relevan dan mengintegrasikan kedalam kerangka kategori yang berkaitan.

\section{Penyajian Data}

Setelah data direduksi, maka langkah selanjutnya yaitu penyajian data atau mendisplaykan data. Penyajian data yang dimaksud adalah sebagai proses analisis untuk merakit temuan data yang ada di lapangan dalam bentuk deskriptif. Dalam menyajikan data penulis mengelompokkan responden dan perilakunya, dan bagaimana perbedaannya sehingga penulis dapat menemukan tema dan pembentukan hipotesis.

\section{Menarik Kesimpulan}

Menarik kesimpulan yaitu menyimpulkan berbagai temuan data yang sudah diperoleh selama proses penelitian berlangsung sehingga dapat ditarik kesimpulan yang akurat.

\section{HASIL DAN PEMBAHASAN}

\section{Faktor Penyebab Jump Ship Crew On} Board pada PT Karya Sumber Energy

Berdasarkan observasi, dokumentasi, dan wawancara kepada karyawan dan beberapa crew kapal yang pernah melakukan jump ship pada PT Karya Sumber Energy maka dapat diperoleh beberapa faktor penyebab jump ship crew on board adalah sebagai berikut:

\section{Faktor Internal}

Faktor internal dari jump ship crew on board adalah faktor yang berasal dari dalam diri crew kapal itu sendiri, yang memiliki kendala maupun $\begin{array}{lcr}\text { permasalahan } & \text { pribadi } & \text { yang } \\ \text { menyebabkan } & \text { crew } & \text { kapal }\end{array}$ meninggalkan tanggung jawabnya sebagai crew kapal. Berikut adalah faktor internal dari jump ship crew on board:

\section{a. Hubungan Crew Kapal}

Dalam suatu organisasi kerja hubungan yang baik akan sangat berpengaruh kepada kepuasan kerja seseorang. Sama halnya yang terjadi didalam organisasi crew kapal dimana kerjasama dan hubungan baik antar crew kapal harus terjalin dengan baik. Hubungan antara crew kapal yang tidak baik akan menimbulkan kepuasan kerja seseorang menurun, sehingga menyebabkan crew kapal merasa tidak nyaman dengan pekerjaannya sehingga melakukan jump ship. Hubungan yang kurang baik ini dapat dipicu dari attitude yang buruk dari crew kapal, pressure atau tekanan dari atasan. Yang dimaksud atasan disini adalah Senior Officer yaitu Nakhoda, Chief officer atau mualim I dan Chief Engineer atau kepala kamar mesin atas pekerjaan crew tersebut diatas kapal. Crew kapal yang tidak sabar dan atau tidak dapat mengsiasati pressure terhadap pekerjaannya ini yang menimbulkan crew kapal melakukan jump ship crew on board:

b. Masalah Intern Keluarga

Menjadi seorang pelaut merupakan pekerjaan yang mengharuskan seorang pelaut untuk jauh dari keluarga dan tempat tinggalnya. Permasalahan keluarga yang mendesak dan tidak dapat 
ditunda

seringkali

menyebabkan seorang pelaut melakukan jump ship crew on board.

\section{c. Ketidak Sesuaian Ekspektasi} Crew

Ketidak sesuaian ekspektasi atau harapan crew terhadap kondisi kapal, agar operasional kapal dapat berjalan dengan lancar, kapal memerlukan maintenance atau perawatan secara berkelanjutan agar kondisi kapal selalu dalam keadaan baik. Jika crew kapal gagal dan atau lalai dalam melaksanakan maintenance akan terjadi trouble atau kerusakan pada kapal. Kondisi kapal yang trouble atau rusak sering kali menyebabkan crew kapal harus melakukan perbaikan-perbaikan yang sering kali membuat crew kapal tidak tahan dengan kondisi kapal saat itu. Kondisi tersebut seringkali membuat crew kapal merasa tidak nyaman sehingga crew melakukan jump ship crew on board.

\section{Faktor Ekternal}

Faktor eksternal dalam jump ship crew on board merupakan faktor yang dipengaruhi oleh kesalahan dari pihak PT Karya Sumber Energy. Kesalahan yang terjadi dibidang personalia adalah masa kontrak crew on board sudah habis namun pihak personalia yang bertanggung jawab atas rekrutmen dan pergantian crew kapal terlambat dalam mengirim pengganti, sehingga crew kapal melakukan jump ship. Faktor eksternal lain yang menyebabkan jump ship crew on board adalah terjadi komunikasi yang kurang baik antara crew on board dengan pihak PT Karya Sumber
Energy. Komunikasi yang kurang baik ini sering disebabkan adanya kerusakan mendadak yang terjadi pada kapal, yang sebelumnya tidak ada laporan dari pihak crew kapal kepada staf PT Karya Sumber Energy, sehingga saat terjadi trobel mendadak pada kapal menimbulkan teguran dari pihak kantor. Teguran yang diberikan staf kantor tersebut jika crew kapal tidak dapat menerima dan atau tersinggung atas teguran tersebut seringkali menjadi permasalahan yang membuat crew kapal melakukan jump ship. Kemudian faktor eksternal lain yang menyebabkan crew jump ship adalah kurang terlaksana dengan baik sistem promosi kenaikan jabatan crew kapal pada PT Karya Sumber Energy seorang crew kapal dapat mendapatkan promosi kenaikan jabatan jika crew tersebut mendapat kondite sangat baik dan mendapat rekomendasi kenaikan jabatan dari Nahkoda untuk crew bagian deck dan kepala kamar mesin untuk bagian engineer atau mesin. Selain itu crew kapal juga dapat mendapatkan promosi kenaikan jabatan jika crew tersebut telah menjalin kontrak kerja laut pada PT Karya Sumber Energy selama tiga tahun dengan kondite baik dalam setiap kontraknya dan telah memenuhi persyaratanpersyaratan baik keahlian maupun sertifikat-sertifikat yang dibutuhkan untuk dapat naik jabatan.

\section{Dampak Jump Ship Crew On Board pada PT Karya Sumber Energy.}

Dampak Jump Ship Crew On Board pada PT Karya Sumber Energy dapat dilihat pada penjelasan berikut: 


\section{Dampak dibidang Operasional.}

Jump ship crew on board akan menganggu kelancaran operasional kapal, karena jump ship crew on board menyebabkan kekosongan posisi atau jabatan yang terjadi dikapal. Jika kapal dalam posisi sandar di pelabuhan atau sedang proses bongkar muat jump ship crew on board akan mengakibatkan terganggunya kelancaran bongkar muat. Selain itu kekosongan jabatan diatas kapal dapat mengakibatkan kapal tidak dapat berlayar, akibat tidak terbitnya surat ijin berlayar dari Syabadar dan Otoritas Pelabuhan setempat, sampai kekosongan jabatan tersebut digantikan.

PT Karya Sumber Energy membuat kebijakan yang menekankan pada pembagian tugas dari setiap jabatan yang ada di atas kapal, kebijakan ini meliputi penggantian sementara kekosongan jabatan yang disebabkan jump ship crew on board oleh atasan maupun bawahan dari crew jump ship tersebut sesuai intruksi dari Nakhoda kapal maupun intruksi dari Designated Person Aschore (DPA) sampai datangnya crew pengganti, tugas dan tanggung jawab yang diberikan kepada crew pengganti sementara ini akan diberikan imbalan berupa uang saku atau gaji yang diberikan senilai dengan gaji crew jump ship berdasarkan lama penggantian jabatan tersebut. Kebijakan ini berlaku apabila jump ship crew on board terjadi saat kapal sandar dan dalam proses bongkar muat. Kebijakan ini dibuat agar tidak terjadi gangguan yang menyebabkan terhambatnya proses bongkar-muat yang dapat menimbulkan kerugian bagi perusahaan.

\section{Dampak di Bidang Personalia}

Jump ship crew on board akan mengakibatkan kekosongan jabatan diatas kapal, untuk mengisi kekosongan jabatan atau posisi inilah yang mengharuskan pihak personalia menggantikan crew kapal yang kabur dengan cepat. Penggantian posisi yang kosong tersebut akan digantikan dengan crew standby. Crew standby ialah crew kapal yang telah selesai menjalankan kontak kerja dengan PT Karya Sumber Energy dan saat ini sedang menunggu kontak selanjutnya dengan PT Karya Sumber Energy, jika tidak terdapat crew standby pada jabatan yang dibutuhkan, maka pihak personalia harus mencari dan menyeleksi crew baru dengan cepat dimana dalam menyeleksai crew baru harus melalui beberapa tahapan yaitu seleksi CV dan pemerikasaan dokumen, interview dengan pihak personalia dan supertenden, dan training crew. Disamping itu penggantian crew yang mendadak akibat jump ship dengan crew standby akan mengganggu planning crew on board atau perencanaan penempatan crew kapal. Perencanaan pergantian crew di siapkan untuk mengantikan crew on board yang akan selesai masa kontraknya dengan PT Karya Sumber Energy.

Upaya yang dilakukan dalam bagian personalia dalam mencegah terjadinya jump ship crew on board yaitu melakukan backlist atau memutus kontrak kerja dan tidak lagi menjalin kontrak kerja kembali dengan crew jump ship. Kemudian pihak personalia lebih memperketat dalam proses perekrutan crew kapal, khususnya saat interview atau wawancara crew baru maupun crew lama, akan dilakukan dengan lebih intensif dan mendalam. Hal ini bertujuan agar pihak personalia dapat mengetahui attitude maupun karakter dari masingmasing crew kapal dan kesiapan crew kapal tersebut untuk menjalankan 
perjanjian kerja laut dengan PT Karya Sumber Energy.

Kemudian sebelum crew kapal menandatangani kontrak kerja dengan PT Karya Sumber Energy crew kapal harus mengikuti training, saat training tersebut crew akan mendapatkan materi tentang jobdis atau tugas dan tanggung jawabnya diatas kapal sesuai jabatan crew diatas kapal dengan mengisi KSE Checklist. KSE Checklist adalah suatu form yang berisi system pelaporan crew kapal pada PT Karya Sumber Energy. Selain itu crew juga akan diberi gambaran tentang kondisi kapal dan keadaan kapal yang akan dinaiki. Hal ini bertujuan agar crew kapal mengenal dan lebih memahami kondisi kapal yang akan dinaiki. Pengenalan ini bertujuan agar saat crew sampai di kapal sudah siap akan kondisi kapal tersebut

Selain itu dari pihak personalia juga membuat file masa layar crew, dalam file ini berisi lama crew kapal menjalin kontrak kerja laut dengan PT Karya Sumber Energy dan kondite crew selama berada di atas kapal. File ini bertujuan untuk mempermudah pihak personalia mengetahui kondit dan berapa lama crew kapal menjalin kontarak kerja laut dengan PT Karya Sumber Energy, sehingga promosi kenaikan jawatan crew kapal dapat berjalan dengan lancar. Disamping itu upaya lain yang dilakukan PT Karya Sumber Energy dalam mencegah jump ship crew on board dengan menjalin komunikasi yang lebih baik antara staff PT Karya Sumber Energy dengan crew on board. Menjalin komunikasi yang baik disini adalah dengan memberi kesempatan untuk kepada crew kapal dalam menyampaikan kendala dan atau permasalahan-permasalahan crew diatas kapal, kemudian menindak lanjutinya dalam rapat intern personalia maupun perusahaan untuk dapat menyelesaikan masalah-masalah yang dihadapi crew di atas kapal.

\section{Dampak Financial atau Keuangan}

Dalam permasalahan jump ship crew on board yang dapat mengganggu operasional kapal hal ini akan mengakibatkan kerugian financial atau keuangan yang akan dialami oleh perusahaan diantaranya adalah biaya terganggunya operasional kapal berupa uang tambat pelabuhan yang membengkak akibat terganggunya proses bongkar muat, biaya anchore kapal saat kapal menunggu datangnya crew pengganti, kemudian dari bidang personalia yaitu biaya perekrutan, perlengkapan crew on board seperti safety shoes, wearpack, sijil buku pelaut dan surat perjanjian kerja laut, uang saku crew dan biaya transportasi crew menuju kapal. Biaya-biaya yang timbul secara mendadak tersebut dapat menjadi kerugian keuangan pagi perusahaan khusunya PT Karya Sumber Energy.

\section{KESIMPULAN}

1. Penyebab terjadinya jump ship crew on board pada PT Karya Sumber Energy ada 2 (dua) faktor yaitu faktor internal dan faktor ekternal. Faktor internal penyebab jump ship on board adalah faktor yang berasal dari crew kapal itu sendiri yang memiliki kendala maupun permasalahan pribadi sehingga meninggalkan tanggungjawabnya sebagai crew kapal. Sedangkan faktor ekternal jump ship crew on board adalah faktor kesalahan dari pihak PT Karya Sumber Energy.

2. Dampak jump ship crew on board pada PT Karya Sumber Energy dapat dilihat dalam bidang operasional, personalia, dan financial atau keuangan. Dalam bidang operasional jump ship crew on 
board berdampak pada terganggunnya operasional kapal akibat kekosongan jabatan yang terjadi di kapal. Kemudian pada bidang personalia jump ship crew on board menyebabkan pihak personalia harus mengganti crew jump ship dengan cepat dan tepat. Sedangkan dalam bidang financial atau keuanggan jump ship crew on board berdampak pada timbulnya biaya-biaya tambahan sehingga merugikan perusahaan.

\section{DAFTAR PUSTAKA}

Burhanudin, 2000, Administrasi Manajemen dan Kepemimpinan, Bumi Aksara.

Hadi, S, 2001, Metodologi Research, Andi Offset.

Jonathan, sarwono, 2006, Metode Penelitian Kualitatif dan Kantitatif, Graha Ilmu.

Kamus Besar Bahasa Indonesia, 2001, Kamus Besar Bahasa Indonesia,
Pusat Bahasa, Departemen Pendidikan Nasional.

Levi, 2002, Faktor Faktor yang Mempengaruhi Kepuasan Kerja, 04 mei 2020 , http:/id.wikipedia.prg/wiki/kepuasan_ kerja

Moleong, L. J., 2007, Metode Penelitian Kualitatif, Remaja Rosda Karya.

Peter, S., \& Salim, Y, 2002, Kamus Besar Bahasa Indonesia Kontemporer, Modern English Press.

Prastowo, D., \& Juliaty, R, 2002, Analisis Laporan Keuangan dan Konsep Aplikasi, Unit Penerbit \& Percetakan AMP YKPN.

Sugiyono, 2006, Metode Penelitian Kuantitatif Kualitatif, Alfabeta.

Sujarweni, 2015, Metodologi PenelitianBisnis dan Ekonomi, Pustaka Baru Press.

Sukardi, 2013, Metode Penelitian Pendidikan Kopentensi dan Praktiknya, Bumi Aksara.

Yusuf, M, 2015, Metode Penelitian Kualitatif, Kuantitatif. \& Penelitian Gabungan, Kencana 